This item is the archived peer-reviewed author-version of:

From dialectics to the diabolical

\title{
Reference:
}

Liska Vivian.- From dialectics to the diabolical

Angelaki: journal of the theoretical humanities - ISSN 0969-725X - 23:3(2018), p. 14-27

Full text (Publisher's DOI): https://doi.org/10.1080/0969725X.2018.1473924

To cite this reference: https://hdl.handle.net/10067/1517610151162165141 


\title{
A N GELAKI
}

journal of the theoretical humanities

volume 23 number 3 june 2018

"vivian liska

\section{FROM DIALECTICS TO THE DIABOLICAL}

adorno's "new music" and blanchot's "ars nova"

\begin{abstract}
In "Ars Nova," a short essay written in 1963, Blanchot defends the "new music" of Arnold Schönberg and his school against its critics and hails it as an exemplary contestation of culture conceived as an attempt to conceal the groundlessness of human existence. The fragmentary and dissonant nature of the "new music" has the power to unmask culture's pretence of order, meaning and harmony. It embodies the potential of modernist art to unsettle all established conventions standing in the way of an authentic, radical interrogation. Blanchot develops his argument by way of a discussion of Adorno's theory of modernist music. The affinities and divergences revealed in Blanchot's reading of Adorno's work shed light on their respective understanding of the disruption enacted by the "new music." A close analysis of Blanchot's essay discloses the role of this confrontation with Adorno's dialectical theory and points to the political and poetic ramifications of a complex and hitherto largely neglected category in Blanchot's thinking about art: the diabolical.
\end{abstract}

Keywords new music; Adorno; Blanchot; diabolical

[T]his artist, rather than being a writer, is a man at the mercy of art par excellence, of music.

Maurice Blanchot ${ }^{1}$

Any work returns [Blanchot] to himself, all thought different from his own forces him to pursue this difference inside himself. Each critical study of Blanchot actually starts by being critical but becomes less and less so. It is the act through which criticism passes from the mental world of another to another world, all intimately his own, that he is the only one to conceive and to explore. However, what else is this new world other than a strictly creative thought?

\section{Georges Poulet ${ }^{2}$}

$\mathbf{M}$ aurice Blanchot's "Ars Nova,"3 a short essay written in 1963 after the publication of the French translation of Theodor W. Adorno's Philosophie der neuen Musik, ${ }^{4}$ is Blanchot's most elaborate and explicit reflection on modern music, in particular the atonal compositions of Arnold Schönberg and his school. One can also read it as a condensed manifesto of his overall vision of modernist art and, in an even wider sense, as a succinct summary of his theoretical thought in those years. Framed as a sweeping defence of twelve-tone music against its detractors, the essay hails the potential of art to contest culture and unmask it as an illusion hiding the groundlessness of human existence. The essay treats the "new music" as an unsettling disruption of established conventions at a time when it had already become canonical and, in many ways, it rehearses older debates about the political affiliations of 
modernist art. It sheds new light, however, on Blanchot's views about the interrelationship between music and literature and illuminates his struggle with the paradoxes of artistic innovation. At the same time, it highlights the radicalism and, arguably, the dangers of his call to face the all-engulfing "exigency of art" exemplified in the "new music." "Ars Nova," perhaps conceived merely as a review of Adorno's book, also paradigmatically illustrates Blanchot's critical method, particularly where he confronts views different from his own.

At the heart of Blanchot's "Ars Nova" lies a discussion of the theory of modernist music developed by Adorno in the 1930s and 1940s. Differences in theoretical orientation - Blanchot's main interest in the ontological space of literature and Adorno's emphasis on the social and historical dimensions of aesthetics - explain why they could be regarded as "incommensurable" thinkers (Allen xvi). Although Blanchot and Adorno, indeed, articulated divergent views on the origin and role of art in modernity and became key figures in the elaboration of theoretical paradigms often considered to be incompatible, ${ }^{6}$ they share many common concerns. Both thinkers formulate a radical critique of culture and the possibilities and conditions under which art can reveal and even counteract its flaws. Their views converge in a shared understanding of art's potential to question the monopoly of reality as a measure for human possibilities. Both turn against unifying and totalizing modes of artistic representation and insist that art can contest "that which is"7 only as an autonomous realm. The conceptualization of crucial elements of modernism such as the incomplete and the negative, as well as the theoretical elaboration of a modernist poetics of fragmentation and discontinuity, owe much to both Blanchot and Adorno. Yet their names are rarely found on the same page, and only recently and in very specific contexts are they considered in relation to each other. ${ }^{8}$

Blanchot mentions Adorno for the first time in 1950, in a footnote to an article titled "Thomas Mann et le mythe de Faust," one of several articles on Mann that he wrote between 1950 and $1963 .{ }^{9}$ Blanchot refers to the German novelist's acknowledgement of the musical advice he received when writing his Doktor Faustus from "Theodor W. Adorno, a composer, sociologist, and theorist of music, who follows the dodecaphonic technique, but searches in it for means of transcending it" (Blanchot, "Thomas Mann et le mythe de Faust" 12). Although he does not mention Adorno again until "Ars Nova," it is clear that Blanchot's portrayal of the "new music" in some of his essays on Mann is to a large extent inspired by Adorno's theories. "Ars Nova," which addresses Adorno explicitly, is the last of these articles on Mann. Its description of the "new music" is fully based on and occasionally almost literally taken from Adorno's Philosophie der neuen Musik. A textual analysis of "Ars Nova" reveals common points between Blanchot's and Adorno's views; it also shows how seemingly slight shifts in Blanchot's paraphrase of Adorno's book eventually lead to major differences in their respective assessment of this music and its philosophical, political, and aesthetic implications. ${ }^{10}$ The affinities and divergences revealed in Blanchot's reading of Adorno's work highlight the stakes in their respective understanding of the disruption enacted by the "new music" and, ultimately, by modernist art as a whole. Blanchot's "Ars Nova" thus presents an opportunity to examine how Blanchot transforms Adorno from one of his potential challengers to an imaginary comrade in arms. An analysis of Blanchot's essay discloses the strategies he employs to blur their differences and present him as an ally for his own thinking. In the course of this process, Blanchot formulates his own vision of the "new music." 
Blanchot's essay consists of four distinct parts: The first polemicizes against disparagers of the "new music," particularly Thomas Mann, who, in his novel Doktor Faustus, associates this music and its violent disruption of order and tradition with National Socialism. In the second section, Blanchot presents an alternative view of the "new music" and describes its characteristics and effects in a discussion of key passages from Adorno's Philosophie der neuen Musik; in the third section, Blanchot focuses on the discontinuous nature of this music, linking it to his reflections on the fragmentary in modernist art in general. The final part, which invokes central concepts of Blanchot's thought such as exteriority and the neutral, considers the farreaching implications of what he believes to be at stake in the "new music" and embeds them in a vision of an alternative, "unfigurable," and negatively inflected space consisting of nothing but questions without answers. At the end of the essay, Blanchot attributes a privileged role to the Ars nova as a pathbreaking inspiration for what remains his primary concern: an articulation of the "exigency of art" and of literature in particular.

Although Adorno figures prominently in only parts of the essay and disappears in the final section, he is undoubtedly Blanchot's main interlocutor. At times, Blanchot's essay seems to battle with more immediate opponents, the adversaries of the "new music" on both sides of the political spectrum. He mentions "socialist leaders," particularly Georg Lukács, who rejected the "new music" on seemingly Marxist, but, in truth, conservative grounds (AN 507; ANE 77), and the Nazis, who forbade it because it did not fit their aesthetics of pathos and grandeur. The most important detractor of the "new music" in the first paragraphs of Blanchot's essay is, however, Thomas Mann, whose name frames the essay. In the opening pages of "Ars Nova," Blanchot faults Mann for associating the "new music" with the "aberrations of National Socialism." Accusing Mann of "intolerance" and "closed-mindedness," Blanchot sharply criticizes his depiction "without great scruples and without much caution" (AN 506; ANE 77; trans. mod.) of the art of the composer Adrian Leverkühn, the main character of Doktor Faustus. Modelling Leverkühn on Schönberg, Mann portrays his music as both a symptom and an agent of the crisis that will lead to the "madness of the Third Reich" and its "pact with the devil," explicitly associated with Hitler (ibid.). Blanchot criticizes Mann for his "condemnation," even "damnation" of the Ars nova, which made this music appear as "socially and politically tainted." He explains this reaction as the fear of a conservative "man of culture" in the face of this music's radical disruption of harmony, unity, and order (AN 506-07; ANE 77; trans. mod.).

"Ars Nova" ends on a puzzling twist: after Blanchot's initial critique of Mann's association of the "new music" with "the innate despair predisposing to a pact with the devil" (AN 506-07; ANE 77; trans. mod.), Blanchot retracts his judgement of Mann's allegations. "The Ars nova is indeed diabolical," Blanchot remarks in the essay's concluding words, adding in parentheses: "(Thomas Mann was thus right in the end)" (AN 514; ANE 84). With these closing words, Blanchot seems to disavow his critique of Mann in the opening paragraphs of "Ars Nova." In the pages between these seemingly contradictory statements, Blanchot discusses Adorno's theory of music. These pages display a silent struggle with Adorno, in particular with his dialectical thinking in which opposites are inextricably dependent on and ultimately 
turn into each other and where art is indissolubly interconnected with history, society, and politics.

By alluding to Adorno's disagreement with Mann's condemnation of the "new music" in the first lines of "Ars Nova," Blanchot aligns him as an ally in defence of his own views. The remainder of the essay negotiates this alliance and, in some critical remarks, but mainly in tiny divergences from formulations in Adorno's Philosophie der neuen Musik [Philosophy of New Music], reveals fundamental differences in the views of the two authors. Developing through a subtle, at times elusive and shifting sequence of quotes, half-quotes, selective summaries, ambiguous paraphrases and gradually increasing divergences from Adorno's text, Blanchot deploys his treatment of a "thought different from his own": rather than opposing it, he uses it to pursue this difference "in himself" (Poulet 489). He thereby both preempts his adversary's argumentative force wherever he is in disagreement with him and, simultaneously, renders more complex and "dis-envelops" - exposes - his own view. "Ars Nova" is a paradigmatic example of this dynamic, and significantly it unfolds in the context of his discussion of the "new music." Just as this music, in Blanchot's description, minimizes "contrapuntal organization," and "move[s] forward only by analysis and by division into structures that are more and more subtle; that is, through a form of composition that will involve differentiation and dissociation" (AN 509; ANE 79; trans. mod.), Blanchot's own discussion of Adorno's views does not proceed primarily by counterargument and opposition but by subtle modulations, indirect distinctions, and minute divergences. The essay thus displays parallels between its method and its description of the "new music" that point to this central dynamic underlying Blanchot's critical thought.

ruptures $<$ Typesetter: "A" heading $>$

Adorno and Blanchot contributed in important ways to discussions about the nature and intensity of the rupture of tradition that occurs in modernist art. Their divergent approaches to this rupture are intimately linked to the paradoxes in modernism's imperative to "make it new": how can modernism reject historicism and its idea of progress, continuity, and, above all, continuous progression of civilization while declaring the imperative of a break that inevitably remains inscribed in the referential framework of history and tradition? To what extent should - and can - this break be detached from that which it disrupts? More generally, how can this break at the core of modernist art both represent and contest its times? In "Ars Nova," Blanchot both adopts and distances himself from Adorno's views of this rupture. Blanchot accepts Adorno's central argument that the "new music" epitomizes modernism's break with aesthetic and cultural conventions, but he rejects the dialectical interdependency of art and its times. He also discards Adorno's explicit emphasis on the rupture's primary function as a critique of society and its cultural practices. Where Adorno praises the "new music's" interruption of totality that breaks open the continuum of tradition and the utter depravity of society, this music is no longer a "mere exponent of society" but a "ferment for its transformation" (PhNM 23). For Blanchot, Adorno's dialectic between the autonomy of art and its historical context renders art too dependent; authentic art must be divested of this dependency on the surrounding world in order to retain its power of contestation. For Adorno, as for Blanchot, the "new music" is, in its radical rationality, internally devoid of history - the former describes it as "infinite in its ahistorical stasis" (PhNM 53) - but this characteristic precisely signifies the 
interruption of history. Whereas Adorno describes the ways in which the "new music" both represents and intervenes in its times and dialectically invokes a momentary, ahistorical interruption of history, Blanchot divests the moment of this break from its historical framework and conceives it on its own terms.

Blanchot thus regards the term "new music" in Adorno's book title as "quite unsatisfactory" (AN 508; ANE 78; trans. mod.) because the word "new" remains embedded in a development, a historical continuity. Adorno, by contrast, fiercely defends the word "new" in this context. In "Musik und neue Musik" [Music and New Music], an essay from 1960, Adorno explains the significance and importance of the word "new" in the title, contrasting it with the "neutral-chronological designation "contemporary" (Adorno, "Musik und neue Musik" 476). In contradistinction to the visual arts, the music of Schönberg and the other Viennese modernist composers ought to keep the term "neue Musik," he claims, because it constitutes a sudden, radical, and unique "shock" that marks art's rupture with modernity gone awry. "New" also indicates the violent detachment from traditional musical forms that engage in the game of the prevalent social conditions of reification and commodity capitalism. Blanchot's dissatisfaction with the term "new," though seemingly innocuous, constitutes the starting point of his disengagement from Adorno's sociopolitical and historical theory of "new music." It prepares the shift towards an understanding of the Ars nova as another space, the image of a sphere "outside" that closes Blanchot's essay.

Blanchot's critical reflection on the term "new music" is an exemplary instance of his attempt to perceive the rupture of modernist art in ontological rather than historical terms and to detach it from dependency on the historical continuity it opposes. The essay's title highlights this emphasis. The term "Ars Nova," which Blanchot adopts from a fleeting comparison in Adorno's book between the "new music" and Florentine early Renaissance music, ${ }^{11}$ opens up a dual perspective: it both invokes a specific, radically innovative moment in the history of music - the invention of polyphony - and divests this moment of its historical specificity. Applying it to other epochal developments in music - something Adorno mentions only by way of an ultimately negative comparison - Blanchot employs the notion of Ars nova to prepare the way for a shift in emphasis from the "new music" to music in general, to a potential in art as such: its opposition to culture. Blanchot's discussion of early twentieth-century "new music" is thus not only a pars pro toto of modernist art but also enacts the potential of an alternative mode of being that is latent in all music and all art.

Blanchot opens his discussion of Adorno's Philosophie der neuen Musik at the beginning of the essay's second part, with a critique of Adorno's use of two terms that embed the modernist rupture in a dialectic of progress and regression, and, by extension, in the concept of stages of human civilization. Blanchot explicitly quotes (but, as will be discussed below, does not faithfully render) a passage from a footnote in Adorno's book:

If atonality may well originate in the decision to rid music of every convention, by the same token, it carries within itself something barbaric that is capable of perturbing always anew the artistically composed surface; dissonant harmony sounds as though it had not been entirely mastered by the civilizing principle of order: in its breaking up, the work of Webern remains almost entirely primitive. ${ }^{12}$ 
Blanchot comments: "Affirmations like these have to be read with prudence. The words 'barbaric' and 'primitive' are hardly appropriate" (AN 508; ANE 78). Avoiding direct confrontation, he then proceeds to explain "what Adorno really means" (AN 509; ANE 79; trans. mod.) when he uses these terms. Blanchot argues that the characteristics of the "new music" - its "total organization of sonorous elements" and its rejection of natural aesthetics - "in a decisive manner contradict the most barbaric conception of music: its critical force, its refusal to accept as eternally valid the wornout forms of culture, and, above all, its violent intention to empty natural sonorous material of any prior meaning" (AN 508-09; ANE 78-79; trans. mod.). In the course of defining the "new music" as an attempt to reach meaninglessness, Blanchot also wants to free the "barbaric" from its temporal dimension of a pre-civilized state; what he retains, however, is the term's force and violence - elements that will eventually feed into what, at the end of his essay, he will call the "diabolical" nature of this music.

Blanchot points out that the word "barbaric" doesn't fit Adorno's own description of this music and, in the process of arguing, he blurs the distinction between Adorno's views and his own. Blanchot deleted important elements from Adorno's quote. Adorno writes: "Not only is the dissonant chord, in comparison with consonance, the more differentiated and advanced, but also it sounds as if the civilizatory principle of order had not yet completely tamed it, as if it were older than tonality" (PhNM 112). In citing Adorno's characterization of "dissonant harmony," Blanchot leaves out the word "advanced" - in the original fortschrittlich - and "older," the temporal reference to earlier times.

Unlike Adorno, Blanchot directly links the two terms "barbaric" and "primitive," omitting several sentences separating the two words in Adorno's quote and, more importantly, effacing their distinctive function and tenor as well as their deliberate ambivalence in Adorno's text. For Adorno, "barbaric" designates something "untamed" that re-emerges in the "new music," but it also has thoroughly negative associations in that it marks the mimetic aspect of the "new music," its contamination by the social conditions of its time. Adorno's use of the term "barbaric" is a crucial instance of his dialectical thinking, in this case the idea that the contemporary barbarism has, due to the "power of social totality," tainted "even such seemingly remote regions as that of music" and, as Adorno writes in the preface of his book, "has produced from itself characteristics of the same nature it resists" (Aus sich heraus Charaktere des gleichen Wesens hervorbringt, dem sie widerstrebt (PhNM 3)). In rejecting the use of the term "barbaric," Blanchot undercuts this dialectical logic and, with it, the specific historical moment to which Adorno's characterization of the violence of the Ars nova relates. He thus absorbs Adorno's argument, but he also distances himself from it in view of his own main argument that all (genuine) art "always surpassed every acquired cultural form" (parce qu'il a toujours dépassé toute forme acquise de culture (AN 511; my emphasis)).

"Primitive" is, for Adorno, even more ambivalent: although it points to an objectionable, regressive artistic tendency, it also contains an element of wild rebellion. Blanchot rejects Adorno's use of the term "primitive" because it implies that this music is endowed with a nostalgic longing for a return to an earlier moment in civilization; this outlook would imply the existence of a natural aesthetics and the idealization of a pre-cultural authenticity. In Adorno's text, "primitive" has, however, both positive and negative connotations and, as with "barbaric," partakes in a dialectic reversal. For Adorno, "primitive" indeed points to an earlier time, but thereby also rebels against the present. In his citation of Adorno's footnote, Blanchot strikingly 
omits a sentence that links the meaning of the "primitive" to a psychoanalytic vocabulary and, more importantly, to a parallel between onto- and phylogenesis that is characteristic of Adorno's dialectic thought: "In its rebellion against conventions," Adorno writes, "progress itself has something of the child, something regressive" (Fortschritt selbst hat im Aufbegehren gegen die Konventionen etwas vom Kind, ein Regressives (PhNMG 46; trans. mine)). In Adorno's text, "primitive," in this context, is associated with the positive register of a rebellious child (later elaborated in the image of a child's defiance against his governess). Furthermore, in Adorno's text, this regressive, "primitive" aspect of the "new music" emerges as "the expression of raw suffering that is unmitigated by convention" ([d]er von keiner Konvention gebändigte Ausdruck ungemilderten Leidens (PhNM 177)) and - as reiterated throughout his book - caused by an oppressive society. Blanchot harbours neither the sympathy for the disobedient child defying authority nor the historical and social index of Adorno's dialectics, that is, those aspects that led Adorno to describe his Philosophie der neuen Musik as a "detailed excursus" to his and Horkheimer's Dialektik der Aufklärung [Dialectics of Enlightenment] (PhNM 11). Detaching Adorno's critique from its connection to the specific historical circumstances of his times, Blanchot embeds Ars nova in a vision of art as unsettling, dangerous, and awesome, thus not barbaric, but a diabolic destroyer of the lie that is culture.

Although Blanchot uses phrases largely adopted from Adorno's work in concluding his objections to the term "primitive," he introduces a barely perceptible shift towards his own vocabulary. Blanchot does adopt from Adorno the violently destructive element of the Ars nova, its power of shattering conventions and any illusion of naturalness, harmony, unity, and wholeness. Blanchot, however, attributes this power to all true art. Unlike Adorno, he does not consider it a "necessary and momentary" interruption of a false wholeness in the face of the current barbaric moment in history. Rather, Blanchot views it, intrinsically rather than dialectally, as the truth of a negativity inherent in the aesthetic experience.

Following his arguments against Adorno's designation of Webern's art as "almost entirely primitive," Blanchot adds a critique of Adorno's contention:

[W]hen it is claimed that the last works of Webern have "liquidated even contrapuntal organization," I think it would be better to say that Webern has in no way freed himself from rigorous counterpoint, but that he has decided we are to hear only its references and traces, in memory of a rigor that is no longer imposed on us except as a reminiscence or as absence, and leaves us as we listen, always free (dangerously free). (AN 509-10; ANE 79-80)

It is unclear why Blanchot writes here, "when it is claimed," in referring to Adorno's discussion of Webern's music. Perhaps this is because what he opposes to the "liquidation of counterpoint" is indeed - dialectically - already there in Adorno's own text, and, more importantly, because Blanchot's paraphrase of Adorno's argument leads to a different place. It is Adorno himself who, in accordance with his philosophy of history, writes:

Webern's late chamber music, at any rate, no longer knows counterpoint as such: Its sparse tones are precisely the remnants left behind by the fusion of the vertical and horizontal dimensions, monuments effectively of a music fallen mute in the "indifference" of its lack of difference. (PhNM 45) 
Blanchot thus, indeed, largely espouses Adorno's terms and his distinction between liquidating counterpoint "as such" and turning it into a mere vestige of earlier times. Blanchot adds, however, a notion that does not feature in Adorno's wording, but is central to Blanchot's thought: the word "absence." 13 Blanchot slides from "reminiscence" to "absence," which accords with his own theory but not with Adorno's dialectics of history. With this addition, Blanchot moves his argument away from Adorno and closer to the emptiness and the néant that will become prominent in the latter part of "Ars Nova." Another important difference appears in the two writers" descriptions of the freedom attained through the disruption of counterpoint. "It is," Adorno writes, "as if music had wrested itself free of any purported natural constraint imposed by its matter and was able to dispose of it freely, consciously, and lucidly." 14 By contrast, Blanchot's "dangereusement libre" added to Adorno's phrases paves the way for the ending of his essay: the encounter with the devil.

Adorno complements his valorization of moments in the past invoked by references to the rebellious child's regression with an orientation towards an explicitly utopian future. In the most rigorous dialectical fashion, Adorno describes the negativity of the "new music's" dissonances as a faithful allegiance to utopia ("Ihre Negativität hält der Utopie die Treue" (PhNMG 68)). He repeats and emphasizes this idea in the last words of the final footnote of his Philosophie der neuen Musik: "The fragmentary (work of art) in its state of absolute negativity signifies utopia" (Das fragmentarische (Kunstwerk) meint im Stande der vollkommenen Negativität die Utopie (PhNMG 120)). Blanchot, by contrast, describes the infinite exigency to which the artistic experience requires us to respond as one "that can be realized only in works given over to the fragment, whose presence suffices to unsettle the entire future of culture and every utopia of happy reconciliation" (AN 511; ANE 81; trans. mod.).

Arguably, utopian traces remain also in Blanchot's description of the new music. Echoing Adorno, he speaks of its emptying out of meaning for the sake of a "promise of meaning"; he quickly adds, however, "or refractory to the order of meaning" (AN 510; ANE 80), a significant difference that negates the utopian component suggested in the promise. Similarly, for Blanchot, the fragment does not "deny all coherence or the value of form" but places itself "beyond aesthetic totality" (AN 509; ANE 79; emphasis mine). These sentences echo Adorno, who writes that dissonance is composed "not in opposition to the eliminated consonances, but in themselves." But in a radical dialectical turn, Adorno adds: "It is in this fashion that they hold true to the historical image of dissonance" (PhNMG 68). Having largely eliminated Adorno's dialectics and, with it, the temporal parameters of past and future, Blanchot's argument proceeds unflinchingly towards the space beyond.

\section{contestations $<$ Typesetter: "A" heading $>$}

Blanchot sees Adorno's approach to the "new music" exclusively as contestation, but he does not specify what Adorno is contesting. In "Ars Nova," Blanchot's main concern lies in art's resistance against its recuperation by culture, which he equates with unity, coherence, and totality. This focus differs significantly in scale and register from Adorno's adversary, the "culture industry" (Kulturindustrie) of capitalist modernity. In one passage, Blanchot comes close to Adorno's critique of Kulturindustrie: he castigates culture's impulse to accumulate works of art in "réserves de civilization" such as "museums, concerts, academies, libraries, records 
and film archives" (AN 511; ANE 81; trans. mod.). This aspect, is, however, subordinate to a much wider critique of culture.

Blanchot associates culture with civilization's impulse to give answers, build systems, and create order. Culture is what shields us from the authenticity of chaos and uncertainty. Genuine art has the power to counteract this falsity. The deception exerted by culture is, for Blanchot, largely independent of its concrete historical and social manifestations. By contrast, Adorno's critique targets the specific sociohistorical incarnation of culture as the mass deception that arose in the eighteenth century and turned partially at the end of the nineteenth century and fully around the First World War into a ruthless system of domination. This system reflects a general social and political development, which Adorno and Horkheimer call verwaltete Welt, the world of administered life. Blanchot is less concerned with mass culture's commodification and reification described by Adorno than with the impulse to unify and totalize altogether. For Adorno, denouncing culture as it manifests itself in late capitalist society must occur for the sake of the truth that the world is in a dismal state; for Blanchot, it signifies the necessity "to enter a new space," a sphere beyond truth that consists of nothing but a "radical interrogation" (AN 514; ANE 84), a negativity beyond repair. For Blanchot, unlike Adorno, genuine art contests not so much the capitalist manifestations of late modernity's reified mass culture but culture as such.

Where Blanchot discusses the "new music" in terms of its "exigence fragmentaire" (fragmentary exigency or exigency of the fragmentary ${ }^{15}$ ), he explicitly moves from time to space: rejecting the nostalgia of a "pre-musical" mode, he hails the exploration of the "infinite space" of the work (AN 510; ANE 80). At this point, he largely abandons the specificity of the "new music": "Art," Blanchot writes, "has always gone beyond all acquired forms of culture" (AN 511; ANE 81). The Ars nova merely enables an "almost immediate" access to the artistic experience as such, an experience that Blanchot describes as "suffering" and "pain" caused by the dislocation, the disruption of any meaning and order underlying all culture (AN 513; ANE 82; trans. mod.). Blanchot, apparently, at this point, has also turned away from Adorno's view that "radical music knows the suffering of men" from alienation, lack of freedom, and the "horrors of history" (PhNMG 102). In Blanchot's "Ars Nova," the suffering heard in the "new music" is, by contrast, the "painful exigency" (exigence douloureuse) of "thought trying to escape the power of unity" (AN 513; ANE 83; trans. mod.). The space beyond is this escape from history, from meaning and culture, from the world as we know it.

The final part of Blanchot's text, which starts with a reiteration of the radical opposition between art and culture, is centred entirely on the description of this "outside" space. Although Adorno is not mentioned any more, the first paragraph of this last section continues to be studded with almost literal, unmarked quotes from Adorno's Philosophie der neuen Musik. The most striking of these quasi-quotes - the passage in which Blanchot seems to be the closest to Adorno's social critique concerns the meaning and function of the coldness and "inhumanity" of the "new music." Blanchot writes: "Rigid, hard, austere, with no spirit of play and without nuance, this music wants to concede nothing to the 'human' that society is always ready to appeal to as an alibi for its own inhumanity" (AN 511; ANE 81). "This sentence is a barely disguised but unmarked quote from Adorno's book: "Advanced music has no other alternative than to insist on its own hardness, without concession to that human that it sees through, whatever attraction its allure still casts, as a mask for inhumanity" (PhNM 19). ${ }^{17}$ 
What is lacking from Blanchot's rendering of Adorno's sentence is the "new music's" capacity to "see through" the mask of the falsely humane: for Adorno, the value of this music lies precisely in "its dialectical cognitive function," 18 its awareness of society's inhumanity. Blanchot also omits Adorno's gesture of regret: this music has "no alternative" but to become hard and cold in the face of an inhuman society. "Under the present conditions," Adorno writes, "the new music is obligated to firm negativity" ([Die neue Musik] ist unter den gegenwärtigen Bedingungen zur bestimmten Negation verhalten (PhNM 20; English translation mine)). In Blanchot's version of this thought, the inhumanity of the "new music" is unhinged from this cognitive function as well as from these "present conditions." It is, instead, an intrinsic element of artistic creation, its source of creativity. This divergence will indeed lead to Blanchot's affirmation of a very specific inhuman force exerted by the Ars nova, a force that does not figure in Adorno's treatment but that features in the sentence with which Blanchot ends his essay: the diabolic nature of the "new music."

\section{the diabolical< Typesetter: "A" heading $>$}

"Ars Nova," which started with a critique of Mann's condemnation of the "new music" as a "symbolic symptom" of the historical crisis leading to the "pact with the devil" identified as Hitler, returns in the end both to the German author and to the notion of the diabolic, but of a different kind. The closing lines of "Ars Nova" hail the diabolic nature of the "new music" as an aesthetic force of destruction and renewal; it has the power to unmask the illusions of culture and open up a deeply unsettling but more authentic existence. The struggle with and against Adorno, which lies between the beginning and the end of the essay, seems like the process that was needed to distil a purely aesthetic manifestation of the diabolical, one no longer tainted by its association with the historical - and all too real - embodiment of darkness and destruction.

In order to reinstate the diabolical as a creative force, Blanchot had to divest it of its historical associations. This occurs in "Ars Nova," where Blanchot transforms Adorno's thought, stripping it of the dialectics that keeps the diabolical and its destructive force moored in history, in society, and in the world. Only after this process can he ultimately re-invoke the diabolical as a source of creativity no longer "socially and politically tainted" (AN 506-07; ANE 77; trans. mod.). In the last lines of the essay, the diabolical is associated with the neutre and the dehors - notions that appear as attempts at safeguarding the disturbing but creative power of the aesthetic experience from a contamination with history: they neutralize the diabolical's possible affinity with the real, historical violence and its murderous demon ${ }^{19}$ invoked at the beginning of "Ars Nova."

Blanchot's negative appraisal of Mann at the beginning of "Ars Nova" contrasts not only with its ending but also contrasts with an earlier article titled "La Rencontre avec le démon" 20 from 1955 in which Blanchot praises Mann's literary oeuvre, particularly Doktor Faustus, for having "found a solution," a "way out" of the crisis of modernity and "a salvation for art" even as it acknowledges its darkest forces and the true artist's necessary "pact with the devil" (RD 213). Although this essay, which also briefly discusses the music of the Schönberg school and seems to constitute the nucleus of Blanchot's depiction of this music in "Ars Nova," does not mention Adorno, some formulations already show significant similarities to Adorno's Philosophie der neuen Musik. ${ }^{21}$ The difference in Blanchot's judgement of Mann and, 
to some extent, Blanchot's description of the "new music" between "Ars Nova" and "La Rencontre avec le démon" is striking: in "Ars Nova," Blanchot dismisses the "new music's" embedding in history in highly complex and indirect ways via his discussion of Adorno; in "La Rencontre avec le démon" the distinction between the aesthetic and the political fascination with the devil is, by contrast, stated explicitly, simply and unambiguously. ${ }^{22}$ This difference is correlated with Blanchot's appraisal of Mann, his reflections on the relationship between art and politics, and, above all, his description of the diabolical nature of the "new music."

In "La Rencontre avec le démon," reflecting on the negative, tragic ending of Mann's Doctor Faustus, Blanchot writes:

Is it the sense of the narrative, its last word? It does not seem so. Because, as has been said, the biographer [the novel's narrator Serenius Zeitblom] and, by all evidence, the novelist himself condemn and judge vain, sterile, and terribly unfortunate demonic drunkenness when it is of a regime and a state; it invites us to think, however, that, in terms of the works and the fate of art, collaboration with the devil is individually tragic, but, from the point of view of culture and spirit, it is surprisingly fertile, happy and worthy of admiration. [...] [A]s works of art, they by no means participate in the crime into which they were born and even less to the damnation of the political society whose excesses they seem to illustrate. ${ }^{23}$

In this passage, Blanchot lauds Mann's differentiation between the demonic dimension of Hitler's regime and the manifestation of the demonic in art. Blanchot concludes that, for Mann - as for Blanchot himself - "there is no solidarity" between this art and the politics of the Third Reich. This approval of Mann is radically opposed to Blanchot's judgement of the author in the first pages of "Ars Nova," where Mann is presented as a bourgeois "frightened" by the "new music" "no less than the masters of the Third Reich" (AN 511; ANE 81).

It is equally striking that, according to Blanchot's assessment in his earlier article, in creating the figure of Leverkühn, Mann evokes Schönberg but does not fully identify his protagonist's art with the Austrian composer's music. Blanchot speaks of the "admirable efforts" of Schönberg and his school, but he praises the figure of Leverkühn and with it Mann's novel because, unlike the radical disruption of the "new music," they "reconcile tradition and innovation" and transform "cold calculation into expressive harmony and warmth of the heart" (la froideur calculatrice y devient harmonie expressive et chaleur du cœur (RD 212)). In "Ars Nova," by contrast, Blanchot praises the "new music" precisely for opposing reconciliation, harmony and warmth. What lies behind Blanchot's change in attitude towards Mann and, more importantly, towards the "new music" between the two essays? And what role, if any, does the explicit mention of Adorno in "Ars Nova" play in the alteration of Blanchot's view?

In the earlier essay Blanchot asks:

What does the artist owe to the devil? Strangely, this: it owes him to have a soul, to have given warmth and humanity to a cold art. The link with the devil may well be nothing more than the secret link with the disease [of the composer Leverkühn in Doktor Faustus], and it is probably not responsible for all the creative moments, but, by freeing them in erasing doubts and 
scruples, by removing the disintegrating critique, it is what releases the primordial inspiration, the divine enthusiasm. ${ }^{24}$

Blanchot describes here both Mann's fascination with the demonic and his own affirmation of the diabolic origin of artistic inspiration. In this passage, the diabolic is described in entirely positive terms as an aesthetic category, an elemental force that unravels the scepticism and wariness of modernity. "Soul," "humanity," and "divine enthusiasm" are the qualities bestowed upon the diabolic aspect of Mann's novel, which Blanchot distinguishes from the "cold art" of the "new music." This diabolic force of art is thus radically distinct from its negative historical manifestation and its embodiment in Hitler. In this earlier essay, where Blanchot does not mention Adorno, paradoxically he describes Schönberg's dodecaphonic system in terms that are close to Adorno's ideas. He discusses the dissonance of the "new music" as an expression of the political conditions of those times and as a warning premonition of "l'Allemagne hitlérienne" (Hitler Germany) (RD 222). Unlike in "Ars Nova," Blanchot depicts atonality less as the destruction of culture than as "human distress and misery that has become expression and scream" ("le malheur et la détresse humaine devenus expression et cri" (RD 212)). In "La Rencontre avec le démon," the diabolic thus has a very different meaning from the one at the end of "Ars Nova," where the demon inhabits the space that is beyond and outside history, the space opened up by the "new music":

What space? [...] An unfigurable Universe (a term henceforth deceptive); a Universe escaping every optical exigency and also escaping consideration of the whole - essentially non-finite, disunited, discontinuous. What about such a Universe? Let us leave this question here and instead ask another: what about man the day he accepts confronting the idea that the curvature of the world, and even of his world, is to be assigned a negative sign? But will he ever be ready to receive such a thought, a thought that, freeing him from the fascination with unity, for the first time risks summoning him to take the measure of an exteriority that is not divine, of a space entirely in question, and even excluding the possibility of an answer, as every response would necessarily fall anew under the jurisdiction of the circle, the figure of figures? This amounts, perhaps, to asking ourselves: is man capable of a radical interrogation? That is, finally, is he capable of literature, if literature turns aside and toward the absence of a book? A question the Ars nova, in its neutral violence, has already addressed to him (and in this a diabolical art: Thomas Mann was finally right). (AN 514; ANE 83-84; trans. mod.)

At the end of "Ars Nova," neither warmth nor humanity prevails in the diabolical. In the place of Mann's "solution for the artist" - a harmonization of humanism and the darkness of art - there is now an infinite questioning; instead of "divine enthusiasm" an "exteriority that is not divine." These differences possibly emerge from Blanchot's first open and direct confrontation with Adorno. In "Ars Nova," he is both Blanchot's ally and adversary: He shares Adorno's belief in the disruptive force of art, but Adorno and his dialectics anchoring art in history also represent the obstacle Blanchot has to face on his way to the space "outside." Adorno seems to be the figure behind the devil in Thomas Mann's Doktor Faustus - an entire literature discusses this personification: ${ }^{25}$ with his dialectics he tempts the humanist artist, the "man of culture," to enter a realm of cold inhumanity beyond the 
established categories of good and evil: like the devil in person, he calls destruction creation and evil good. For Mann, who did not trust this dialectical promise and its call for a sacrifice of tradition, order and culture, Adorno might well have been this devil. For Blanchot, by contrast, Adorno's thought possibly contains not too little but still too much humanism, too much world, too much promise of a utopian reconciliation, but also, therefore, too much historical reality attached to the diabolical. In "Ars Nova," the distinction between the political demonic of the Third Reich and its artistic counterpart is no longer, as in 1955, conceptually juxtaposed and distinguished, but literally torn apart between the beginning and the end of the text.

There is, however, a simpler and more immediate explanation for this change from the earlier to the later description of the diabolic; the early text, in which the aesthetic diabolic is benevolent and redemptive (and can be distinguished simply and directly from the political demonic) discusses literature - Mann's novel - whereas the later text, "Ars Nova," which ends on a starker, more threatening and destructive note (and therefore has to be more radically distanced from history and politics) is about music. Perhaps Blanchot can conjure the diabolical more readily where he writes about literature, which, inevitably, remains more immersed in culture and the world, and is therefore also more shielded, can risk more safely than music the encounter with the devil? Blanchot and Adorno are in agreement on this point: for Blanchot, music puts the artist more radically "at the mercy of art" than literature (Blanchot, $\mathrm{La}$ Condition critique 170). Adorno writes that, contrary to the eye that can be closed, "the open organ of the ear is exposed to stimulation without protection" (Das Auge kann man schließen [...] Das offene Organ des Ohrs aber ist dem Reiz schutzlos ausgeliefert). ${ }^{26}$ Possibly, this greater exposure to music explicates why Blanchot, in his writings, occasionally invokes musical elements such as song or sound as a "model" for the potential of art to radically contest or even "destroy" culture. If he nevertheless largely remains within the realm of literature, it is precisely because it skirts the abyss, but also ultimately saves from it. Literature goes as far as possible in turning against culture while at the same time, however precariously, staying in the world. This may also explain why, for Blanchot, it is music, the music of the Ars nova, that can ask the question whether "man is capable of literature, if literature turns aside and toward the absence of a book" (AN 514; ANE 84; trans. mod.) - that is, where literature is no longer safely ensconced between covers that turn it into a harmless cultural artefact. If it is the Ars nova that can ask this question, it is because, as the epitome of what is unsettling in music, as "art par excellence," it exposes the listener to a "neutral violence" that puts us, unprotected, at the mercy of the devil.

\section{disclosure statement $<$ Typesetter: "A" headling $>$}

No potential conflict of interest was reported by the author.

notes 
1 Translation mine. “[Q]ue cet artiste, plutôt qu'un écrivain, soit un homme livré à l'art par excellence, la musique" in Blanchot, "Le Docteur Faustus" 17, reprinted in Blanchot, La Condition critique 170. In the case of quotations for which no official translation exists, the original appears in a footnote. Some official translations have been modified, which is indicated in the in-text references by "trans. mod."

2 Translation mine.

Toute œuvre le renvoie à lui-même, toute pensée différente de la sienne l'oblige à poursuivre cette différence au fond de lui. Chaque étude critique de Blanchot commence effectivement par être critique mais le devient de moins en moins. Elle est l'acte par lequel la critique passe du monde mental d'autrui à un autre monde, tout intime de lui-même, qu'il est seul à concevoir et à explorer. Or, <Query: why is there English "Or" in this French-language quote? It's « Or » in French, which means something like « but now » It's correct, just leave it as it is $>$ qu'est-ce que ce monde nouveau, sinon une pensée proprement créatrice? (In Poulet 489)

In a similar vein, Leslie Hill (109) writes: "Blanchot's strategy is [...] to accompany the text along a certain trajectory in order to propel it into an aporia of its own making." See also Bürger 87; and, most elaborately, the introductory chapters of Hoppenot, particularly the section "De la copie au texte: la paraphrase comme acte critique" 86-90.

3 Blanchot, “Ars Nova," first published in La Nouvelle Revue française 125 (May 1963): 879-87, and reprinted in L'Entretien infini 506-14. References in the text, indicated as (AN page number), refer to the original in L'Entretien infini. The English translation of this text is taken from Blanchot, "Ars Nova," trans. Donald Schier 7684. References to this translation are indicated as (ANE page number). Wherever the translation has been modified, indicated as (ANE page number; trans. mod.), the alternative translation refers to Blanchot, The Infinite Conversation 345-50.

4 Adorno, Philosophie der neuen Musik. Unless otherwise indicated the English translations are taken from Adorno, Philosophy of New Music. References to this text are from the English translation and are indicated as ( $\mathrm{PhNM}$ page number).

5 This remarkable study is the only book devoted entirely to a discussion of the relationship between Blanchot and Adorno.

6 This discussion prefigures in many ways the proximity and differences between two of the foremost paradigms in Critical Theory, the Frankfurt School and French deconstruction.

7 Cf. Blanchot's use of the expression "contestation de ce qui est" in Blanchot, L'Amitié 80.

8 Cf. Hartman; Kofman; Rothberg 25-106; Liska 80-100. 
liska

9 A brief review of the French translation of Thomas Mann's novel Joseph und seine 
Brüder was already published in L'Insurgé 14 (14 Apr. 1937): 5.

10 Allen calls Blanchot's description of the "new music" a "summary" and a "paraphrase" of Adorno's argument. He overlooks, however, the highly significant, though mostly subtle or even hidden differences Blanchot introduces in his rephrasing of Adorno's text.

11 Adorno, in a footnote describing the atonality of the "new music," points both to the liberation from traditional constraints of the twelve-tone system as well as to its "constraining" methodological construction, thus invoking both Schönberg's early and his later oeuvre. Unlike the notion of a "new music," "Ars nova," which refers to early polyphony, emphasizes only the moment of breaking conventions characterizing the composer's early work rather than his new system of composition. Blanchot thereby highlights the transgressive aspect of Schönberg's music.

12 Translation mine. The reference is to the German original: Adorno, Philosophie der neuen Musik 46. Further references to the German original are indicated in the text as (PhNMG page number). The translation of these passages is always mine.

13 The prevalence of the notion of "absence" in Blanchot's writings and in poststructuralist thought in general is linked to its "negative" ontological rather than historical orientation.

14 Adorno discusses the "difficulties following from this freedom" (PhNM 81-82), but he talks about the composers" task in technical and "unheroic" terms.

15 On the difference between these two interpretations of Blanchot's "exigence fragmentaire," see Cools 362-69.

16 "[La musique nouvelle] est rigide, dure, austère, sans esprit de jeu, sans nuance, et elle ne veut rien concéder à cet 'humain' dont la société est toujours prête à se réclamer comme d'un alibi à sa propre humanité" (AN 511; ANE 81; trans. mod.). A similar sentence appears earlier in the essay "Le Docteur Faustus" from 1950: "Pour rester humain et pour exprimer l'humain, l'art doit prendre appui sur l'inhumain, c'est à dire sur le néant" (La Condition critique 171; trans. mine).

17 This thought is intensified in the final lines of Adorno's book: "For the sake of the human, the inhumanity of art must overtop that of the world" (Die Unmenschlichkeit der Kunst muß die der Welt überbieten um des Menschlichen willen (PhNM 102)).

18 Adorno, Essays on Music 394 quoted in Allen 79.

19 Blanchot uses the terms demon and devil/diabolic interchangeably.

20 Blanchot, "La Rencontre avec le démon" 83-102. Reprinted in Blanchot, $L a$ Condition critique 205-25. References to "La Rencontre avec le démon" are to La Condition critique and are indicated as (RD page number).

21 These passages might, however, be derived from Mann's novel, which contains long excerpts directly inspired by Adorno's book. 
22 In another passage in "La Rencontre avec le démon," Blanchot admits that the aesthetic fascination with the devil is difficult to uphold "in the contemporary world, where dark forces are becoming reality and turn into the madness and excess that led, in Germany, to the catastrophe of 1945" (RD 217).

23 Translation and emphasis mine.

Serait-ce donc là le sens du récit, son dernier mot? Il ne semble pas. Car, comme il a été dit, autant le biographe et, de toute évidence, le romancier luimême condamne et juge vaine, stérile et effroyablement malheureuse l'ivresse démoniaque quand elle est celle d'un régime et d'un état, autant il nous invite à penser que, sur le plan des œuvres, dans le destin de l'art, la collaboration avec le démon est individuellement tragique, mais, du point de vue de la culture et de l'esprit, étonnamment féconde, heureuse et digne d'admiration [...] Mais, en tant qu'œuvres d'art, elles ne participent nullement à la faute d'où elles sont nées et encore moins à la condamnation de la société politique dont elles semblent illustrer la démesure. (RD 222)

24 Translation mine.

Que doit l'artiste au démon? Ceci, qui est étrange: il lui doit d'avoir une âme, d'avoir donné à un art froid la chaleur et l'humanité. Le lien avec le démon peut bien n'être que le lien secret avec la maladie [of the composer Leverkühn in Doktor Faustus], n'est sans doute pas responsable de tous les moments créateurs, mais, en les libérant, en effaçant les doutes et les scrupules, en supprimant la critique désagrégeant, c'est elle qui autorise la vieille inspiration primordiale, l'enthousiasme divin. (RD 213)

25 For an overview and some salient examples such as Jean-François Lyotard's essay "Adorno as the Devil," see Leslie's illuminating study Adorno as the Devil in Thomas Mann's "Doctor Faustus."

26 Translation mine. Adorno, “Anweisungen zum Hören neuer Musik” 190.

bibliography

Adorno, Theodor W. "Anweisungen zum Hören neuer Musik." Der getreue Korrepetitor. Lehrschriften zur musikalischen Praxis, Gesammelte Schriften 15. Frankfurt am Main: Suhrkamp, 1976. 188-248. Print.

Adorno, Theodor W. Essays on Music. Ed. Richard Leppert. Berkeley: U of California P, 2002. Print.

Adorno, Theodor W. "Musik und neue Musik." Gesammelte Schriften 16. Frankfurt am Main: Suhrkamp, 2003. 476-92. Print.

Adorno, Theodor W. Philosophie der neuen Musik, Gesammelte Schriften 12. Frankfurt am Main: Suhrkamp, 1975. Print. 
Adorno, Theodor W. Philosophy of New Music. Trans., ed., with a foreword by Robert Hullot-Kentor. Minneapolis and London: U of Minnesota P, 2006. Print.

Allen, William S. Aesthetics of Negativity: Blanchot, Adorno and Autonomy. New York: Fordham UP, 2016. Print.

Blanchot, Maurice. L'Amitié. Paris: Gallimard, 1971. Print.

Blanchot, Maurice. "Ars Nova." First published in La Nouvelle Revue française 125 (May 1963): 879-87. Print.

Blanchot, Maurice. "Ars Nova." Trans. Donald Schier. Perspectives of New Music 17.2 (1979): 76-84. Print.

Blanchot, Maurice. La Condition critique. Articles 1945-1998. Paris: Gallimard, 2010. Print.

Blanchot, Maurice. "Le Docteur Faustus.” L'Observateur 8 (1 June 1950): 17.

Blanchot, Maurice. L'Entretien infini. Paris: Gallimard, 1969. Print.

Blanchot, Maurice. The Infinite Conversation. Trans. Susan Hanson. Minneapolis and London: U of Minnesota P, 1993. Print.

Blanchot, Maurice. "La Rencontre avec le démon." Hommage à la rencontre de la France avec Thomas Mann à l'occasion de son quatre-vingtième anniversaire. Paris: Flinker, 1955. 83-102. Print.

Blanchot, Maurice. "Thomas Mann et le mythe de Faust." Critique 41 (Oct. 1950): 321. Print.

Bürger, Peter. Ursprung des postmodernen Denkens. Göttingen: Velbrück, 2000. Print.

Cools, Arthur. "Reflexions sur l'exigence fragmentaire." Ed. Eric Hoppenot and Dominique Rabaté. Blanchot. Cahiers de l'Herne. Paris: Herne, 2014. 362-69. Print.

Hartman, Geoffrey H. “Blanchot's Silence: Language after the Holocaust.” MS.

Hill, Leslie. Blanchot: Extreme Contemporary. London: Routledge, 1997. Print.

Hoppenot, Eric. Maurice Blanchot et la tradition juive. Paris: Kimé, 2015. Print.

Kofman, Sarah. Paroles suffoquées. Paris: Galilée, 1987. Print.

Leslie, Laura. Adorno as the Devil in Thomas Mann's "Doctor Faustus": Aspects of Modernism in Music, Literature and Critique. Web. 5 Oct. 2017. $<$ http://theses.gla.ac.uk/5233/>. 
Liska, Vivian. "Two Sirens Singing: Literature as Contestation in Maurice Blanchot and Theodor W. Adorno." The Power of Contestation: Perspectives on Maurice Blanchot. Ed. Kevin Hart and Geoffrey H. Hartman. Baltimore and London: Johns Hopkins UP, 2004. 80-100. Print.

Poulet, Georges. "Maurice Blanchot critique et romancier." Critique 229 (June 1966): 485-97. Print.

Rothberg, Michael. Traumatic Realism: The Demands of Holocaust Representation. Minneapolis and London: U of Minnesota P, 2000. Print.

Vivian Liska

Department of Literature and Philosophy

University of Antwerp

Prinsstraat 13 L.400

BE-2000-Antwerpen

Belgium

E-mail: vivian.liska@uantwerpen.be 